\title{
Rooting System of Rice Cultivated under System of Rice Intensification (SRI) Method which Improving Rice Yield
}

\author{
Nurul Hidayati', Triadiati Triadiati ${ }^{*}$, Iswandi Anas $^{3}$ \\ ${ }^{1}$ Plant Biology Study Program, Graduate School, Bogor Agricultural University, IPB-Darmaga Campus, Bogor, Indonesia \\ ${ }^{2}$ Department of Biology, Faculty of Mathematics and Natural Sciences, Bogor Agricultural University, Bogor, Indonesia \\ ${ }^{3}$ Soil Biotechnology Division, Faculty of Agriculture, Bogor Agricultural University, IPB-Darmaga Campus, Bogor, Indonesia
}

\section{ARTICLE INFO}

Article history:

Received March 11, 2016

Received in revised form November 17, 2017

Accepted January 23, 2018

KEYWORDS:

soil redox potential (Eh),

aerenchyma,

root hairs,

root respiration

\begin{abstract}
The development of plant roots is known to play a very important role in the uptake of water and nutrients by rice plants. However, there are few studies on what changes, if any, are induced in the rooting systems of rice plants under System of Rice Intensification (SRI) management. This research evaluated changes of rice roots with SRI method compared to conventional method of irrigated rice cultivation and assessed influences that could improve rice yield. Under SRI management, plant roots were significantly longer and heavier than with conventional method. SRI method also increased the number of root hairs by $60 \%$, and root hairs were healthier and more vigorous compared with conventional method. However, root respiration was not different in the two methods. There was less formation of aerenchyma (air pockets) in rice roots with SRI method, as both the number and size of root aerenchyma were lower with SRI than with conventional method. The SRI method was able to improve the root length, root dry weight compared to the conventional method. The SRI method was also able to increase the number of root hairs by $60 \%$ compared with the conventional method. Eh measurements in the soil with SRI method were higher than with conventional method. However, there was no significant different in root respiration. The aerenchyma formation of rice roots in SRI method was lower than conventional method.
\end{abstract}

\section{Introduction}

The System of Rice Intensification (SRI) is a method of rice cultivation that aims to improve the growth and development of rice plants through changes in crop and water management rather than by depending on new varieties and external inputs. The SRI methodology was developed in Madagascar to benefit smallholding farmers by raising the productivity of their land, labour, water and seed (Laulanie 1993). Significant increases in rice yield when cultivating with SRI method under a wide range of ecological/climatic conditions have been reported by many researchers. The SRI method has been adopted by various countries, now over 50 , and the research on the SRI method continues to focus on how to manage plants, soil, water and nutrients better to promote the growth and functioning of their root systems so that rice plants have an optimum growing environment (Uphoff 2005).

With transplanted irrigated rice, the ability of the roots to resume their growth promptly after

\footnotetext{
* Corresponding Author.

E-mail Address: adiatiipb@gmail.com
}

transplanting, not to have growth suspended for 7-14 days ('transplant shock') is key to the success of transplanting as this should retain rather than thwart root growth potential. Conditions in the nursery that affect seedlings' vigor and their retention of potential include water supply (neither too much nor too little), fertilization (organic and/or inorganic), density of seedlings, and the timing and manner of transferring them from nursery to field (Kramer and Boyer 1995).

Single seedling planting and wide spacing with SRI method ensure that the plant has enough space to spread and deepen its roots, as well as develop a large canopy for intercepting sunlight. Maintaining soil moist but not flooded in the SRI methodology makes plants' rhizosphere well-aerated and their rooting condition are more oxidized (Hidayati et al. 2014). Given the recommendations for SRI management, which gave root growth and health, it is to be expected that the development of rice roots will be optimal or at least close to optimal. Good root growth and functioning will make additional water and minerals available to the plant (Kozlowski 1997). 
When rice plants are grown in continuously saturated (hypoxic) paddy soils, their growth is diminished and their functioning is compromised by disintegration of their roots. In flooded soil, about $75 \%$ of rice roots remain in the top $6 \mathrm{~cm}$ of the soil, where there is more oxygen available (Kirk and Solivas 1997). Moreover, when the soil is kept continuously flooded, plant roots suffer because the supply of oxygen is minimal, and a majority of rice roots degenerate by the phase of flowering (Kar et al. 1974). Therefore, the rooting systems of rice plants under SRI method and conventional method should be studied and compared.

There are few reports on the impact of SRI cultivation methods on the rooting systems of rice plants, the research by Barison being a noteworthy exception (Barison and Uphoff 2010). That study, however, did not examine the morphology and physiology of roots under different management regimes. Therefore, this research undertook to evaluate such characteristics in the rice root systems with SRI compared to conventional rice-growing methods and to account their influence on improving rice yield.

\section{Materials and Methods}

This research was conducted in paddy field, West Java, Indonesia. The materials used were Ciherang variety of rice; and urea-based fertilizer $(45 \% \mathrm{~N})$, SP-36 fertilizer $\left(39 \% \mathrm{P}_{2} \mathrm{O}_{5}\right)$, $\mathrm{KCl}$ fertilizer $\left(60 \% \mathrm{~K}_{2} \mathrm{O}\right)$, and compost enriched with plant growth-promoting rhizobacteria (PGPRs) (Bacillus sp., Pseudomonas sp., Azospirillum sp., and Azotobacter sp.).

Measurement of soil redox potential (Eh) was done by Eh meter PRN-41 DKK TOA(Japan); measurement of root respiration was determined according Verstraete (Anas 1989; Fu et al. 2008) methods. The anatomical parameters were observed by Scanning Electron Microscope (SEM) JEOL JSM-5310LV type.

The study was conducted using trials laid out in randomized block design (RBD) in which the methods of rice cultivation evaluated were the conventional method (Con.) and the System of Rice Intensification (SRI) method. Each treatment was replicated five times, and the size of the experimental plots was $4 \mathrm{~m} \times 5 \mathrm{~m}\left(20 \mathrm{~m}^{2}\right)$.

\subsection{Rice Cultivation}

Seedling preparation was done by soaking the seeds in warm water for 24 hours, then air-draining and incubating them for 2 days until the seeds germinated. In SRI method, the seedlings were planted in a tray, with soil and organic fertilizers enriched by bio-fertilizers $(1: 1 \mathrm{v} / \mathrm{v})$, for 10 days. Meanwhile, for the conventional method, seeds that had been incubated for 2 days and germinated were sown into a standard nursery for 25 days before transplanting with usual practices. The main differences between conventional and SRI rice cultivation methods are described in Table 1 .

Both SRI and conventional methods used the same type, dose, timing, and application of fertilizers, so soil nutrient amendments were not a variable in these trials. There is some evidence from factorial trials that fully organic fertilizer with the other SRI method gives higher yield than inorganic fertilizer (Uphoff and Randriamiharisoa 2002), while other evidence suggests that integrated nutrient management will give best results (Lin et al. 2011). But here we did not evaluate this as a factor affecting rice plants' performance and production.

In these trials, the fertilizer applications were $50 \%$ inorganic (125 kg urea/ha, $100 \mathrm{~kg}$ SP-36/ha, and $50 \mathrm{~kg}$ $\mathrm{KCl} /$ ha, equivalent to $250 \mathrm{~g}$ urea/plot, $200 \mathrm{~g}$ SP-36/plot, and $100 \mathrm{~g} \mathrm{KCl} / \mathrm{plot}$ ) and $50 \%$ organic ( $2.5 \mathrm{t} / \mathrm{ha}$, equivalent to $5 \mathrm{~kg} / \mathrm{plot}$ ). The organic fertilizers used in this research were compost enriched with bio-fertilizers, applied at transplanting along with the SP-36 and $\mathrm{KCl}$ fertilizer, while urea was applied in split doses at transplanting and again at 35 days after planting (rice in conventional method was aged 60 DAS; rice in SRI method was aged 45 DAS).

In the SRI method, to keep the soil moist, a trench along the inner edge of the plot (size $20 \mathrm{~cm}$ x $20 \mathrm{~cm}$ with the depth of $30 \mathrm{~cm}$ ) was flooded with water. Flooding of the plot was done shortly before the time of weeding with a water level about $2 \mathrm{~cm}$.

Weeding of the SRI plots was done at 10, 20, and 30 days after planting using a conoweeder that aerated the topsoil. In the conventional method plots,

Table 1. Comparison between conventional rice cultivation method and SRI method

\begin{tabular}{|c|c|c|}
\hline Planting & $\begin{array}{l}\text { Conventional } \\
\text { (Con.) }\end{array}$ & $\begin{array}{l}\text { System of Rice } \\
\text { Intensification } \\
\text { (SRI) }\end{array}$ \\
\hline $\begin{array}{l}\text { Age of transplanted } \\
\text { seedlings }\end{array}$ & $\begin{array}{l}25 \text { days after } \\
\text { sowing }\end{array}$ & $\begin{array}{l}10 \text { days after } \\
\text { sowing ( } 60 \% \text { less) }\end{array}$ \\
\hline Spacing & $20 \mathrm{~cm} \mathrm{x} 20 \mathrm{~cm}$ & $\begin{array}{l}25 \mathrm{~cm} \times 25 \mathrm{~cm} \\
\text { (25\% wider) }\end{array}$ \\
\hline $\begin{array}{l}\text { Number of } \\
\text { seedlings per hill }\end{array}$ & $\begin{array}{l}3 \text { seedlings } \\
\text { per hill }\end{array}$ & $\begin{array}{l}1 \text { seedling per hill } \\
\text { (33\% fewer) }\end{array}$ \\
\hline $\begin{array}{l}\text { Number of } \\
\text { seedlings per m² }\end{array}$ & $\begin{array}{l}75 \text { seedlings } \\
\text { per } \mathrm{m}^{2}\end{array}$ & $\begin{array}{l}16 \text { seedlings per } \mathrm{m}^{2} \\
\text { (80\% fewer) }\end{array}$ \\
\hline $\begin{array}{l}\text { Number of hills } \\
\text { per } \mathrm{m}^{2}\end{array}$ & 25 hills per $\mathrm{m}^{2}$ & $\begin{array}{l}16 \text { plants per } \mathrm{m}^{2} \\
(36 \% \text { fewer) }\end{array}$ \\
\hline Irrigation & $\begin{array}{l}\text { Flooding } \\
\text { continously }\end{array}$ & $\begin{array}{l}\text { Soil was kept } \\
\text { moist }\end{array}$ \\
\hline
\end{tabular}


irrigation water was supplied continuously, maintaining a water level of about $5 \mathrm{~cm}$ until 105 DAS. Weeding of the conventional method plots were performed at 10 and 20 days after planting by pulling up the weeds by hands. For both cultivation methods, water was drained five days before harvest. Harvesting of both SRI and conventional plots were done when the rice grains had yellowed to around $90-95 \%$, which was 110 DAS.

Observations of rice roots were made of the longest root and the root dry weight at 110 and 70 DAS, root respiration at four phases of growth (vegetative, flowering, grain filling, and mature stage), root aerenchyma, root hairs, at 70 DAS. Observation of soil Eh was done at 55 DAS.

\subsection{Root Respiration}

The measurement of root respiration was determined according to the Verstraete method (Anas 1989; Fu et al. 2008) methods. It was carried out by inserting $300 \mathrm{~g}$ of soil into the root chamber with diameter of $5 \mathrm{~cm}$ and length of $25 \mathrm{~cm}$. The rice roots were inserted into the root chamber containing soil. In the root chamber, there was a hose that connected the root chamber to a bottle containing $15 \mathrm{ml}$ of $0.2 \mathrm{~N}$ $\mathrm{KOH}$. The $\mathrm{CO}_{2}$ produced was accommodated inside the bottle. The root chamber and the $\mathrm{CO}_{2}$ reservoir bottle were closed tightly using vaseline and were incubated for 5 days.

At the end of incubation, 2 drops of phenolphthalein were added into a bottle containing $0.2 \mathrm{~N} \mathrm{KOH}$. The addition of phenolphtalein would cause the clear liquid turn red. Subsequently, titration was done using $0.2 \mathrm{~N} \mathrm{HCl}$ until the red colour disappeared. The volume of $0.2 \mathrm{~N} \mathrm{HCl}$ needed to change the red colour to make the liquid clear was recorded.

After that, 2 drops of methyl orange were added in to the bottle. The addition of this would result in the clear liquid turn yellow. Titration was done using $0.2 \mathrm{~N} \mathrm{HCl}$ until the yellow colour changed to pink. The volume of $\mathrm{HCl}$ needed to change the yellow to pink was recorded. The amount of $\mathrm{CO}_{2}-\mathrm{C}$ of roots produced per kilogram of moist soil per day ( $\mathrm{r}$ ) can be calculated by the formula:

$$
r=\frac{\{(b-c) \times t \times 120\}-\{(a-c) \times t \times 120\}}{k / n}
$$

$\mathrm{a}=\mathrm{ml}$ of $\mathrm{HCl}$ for soil samples

$\mathrm{b}=\mathrm{ml}$ of $\mathrm{HCl}$ for example soil + roots

$\mathrm{c}=\mathrm{ml} \mathrm{HCl}$ sample (empty)

$\mathrm{t}=$ normality of $\mathrm{HCl}(0.1 \mathrm{~N})$

$\mathrm{k}=$ root dry weight

$\mathrm{n}=$ days of incubation
Measurements of root respiration were performed four times. The measurements were taken at vegetative, flowering, grain filling, and mature grain stages.

\subsection{Root Aerenchyma}

The root aerenchyma and root hairs were observed by Scanning Electron Microscope (SEM). The sample preparation was determined according to the (Bozzola and Russel 1999) method, in the following steps: the 70 DAS-aged root samples were cut $\geq 1 \mathrm{~cm}$ from the root tip for observation of root hairs and root aerenchyma. The samples were pre-fixated in $2.5 \%$ glutaraldehyde solution for 12 hours at $4^{\circ} \mathrm{C}$, then were post-fixated in the $2 \%$ tannic acid solution for $1 \mathrm{~h}$ at $4^{\circ} \mathrm{C}$.

Subsequently, the samples were washed with cacodylate buffer solution for 4 times, each stage lasted 15 minutes at $4^{\circ} \mathrm{C}$. The samples then were washed with distilled water for $15 \mathrm{~min}$ at $4^{\circ} \mathrm{C}$. Dehydration process was done in a series of ethanol solutions of $50 \%, 75 \%$, $85 \%, 94 \%$ and absolute alcohol. The dehydrated samples then were freeze-dried (freeze drying) in t-butanol solution for 3 hours, after previously being soaked twice in t-butanol solution for 10 minutes. The specimens were glued on the stub using an adhesive carbon, were plated with gold (metal coating), then were then observed using SEM type JEOL JSM-5310LV.

Percentage of root aerenchyma area was calculated as the sum of the actual cross sectional areas of aerenchymatous space observed. The percentage of the total area of aerenchyma in the cortex of the root was compared between the two cultivation methods in cross section taken $\geq 1 \mathrm{~cm}$ from root tip (Purnomobasuki and Suzuki 2004; Yukiyoshi and Karahara 2014).

Aerenchyma area (\%) = $100 \times$ (area of aerenchyma/ total cross-sectional area)

\subsection{Data analysis}

All the data were analyzed statistically using the Independent t-test at $5 \%$ probability.

\section{Results}

The System of Rice Intensification (SRI) method significantly $(\mathrm{P}<0.05)$ increased the length of the longest roots by $16 \%$ at 110 day after sowing (DAS, at harvest) compared to the conventional method (Table 2). The SRI cultivation method was also significantly $(\mathrm{P}<0.05)$ able to increase the root dry weight of rice plants by $65 \%$ and by $67 \%$ at 70 DAS and at 110 DAS, respectively, compared to the conventional method (Table 2).

The number of root hairs of rice plant in the SRI method was significantly higher $(\mathrm{P}<0.05)$ compared to 
the conventional method. Application of SRI method increased the number of root hairs by approximately $60 \%$ (Table 3). Root hairs on SRI rice plant as observed by the Scanning Electron Microscope (SEM) showed better and healthier conditions, being rigid (straight) and long, while the root hairs on the conventional method plants looked not robust (wilted) and shorter (Figure 1).

Continuous flooding with conventional cultivation method affected the soil redox potential (Eh). This parameter was significantly higher $(\mathrm{P}<0.05)$ with SRI method compared to conventional method of cultivation. The soil Eh in the SRI method plots was $-135.8 \mathrm{mV}$, whereas in the conventional method plots it was -246.6 $\mathrm{mV}$ (Figure 2). However, root respiration of rice plants grown with SRI method was not significantly different $(\mathrm{P}>0.05)$ from that with conventional method in the different developmental phases (Figure 3).

The percentage of aerenchyma formation of rice roots with the SRI method was significantly lower $(\mathrm{P}<0.05)$ compared with conventional method.

Table 2. Effect of cultivation methods on root length and root dry weight at 70 and 110 days after sowing (DAS)

Rice cultivation Root length $(\mathrm{cm})$ Root dry weight $(\mathrm{g})$ method 70 DAS 110 DAS 70 DAS 110 DAS Conventional $32.0 \pm 1.56 \mathrm{a} 23.4 \pm 1.05 \mathrm{~b} 7.4 \pm 2.21 \mathrm{~b} \quad 2.2 \pm 0.18 \mathrm{~b}$ SRI $34.1 \pm 1.24$ a $27.1 \pm 0.24$ a $14.2 \pm 1.14$ a $3.6 \pm 0.24$ a

The same letter in the same column was not significantly different with Independent t-test at $a=0.05$

Table 3. Effect of cultivation methods on root hairs at 70 day after sowing

\begin{tabular}{lc}
\hline Rice cultivation method & $\begin{array}{c}\text { Number of root hairs } \\
\left(\text { number } / \mathrm{mm}^{2}\right)\end{array}$ \\
\hline Conventional & $510.2 \pm 67.49 \mathrm{~b}$ \\
SRI & $816.2 \pm 25.51 \mathrm{a}$ \\
\hline
\end{tabular}

The same letter in the same column was not significantly different with Independent $t$-test at $a=0.05$
Aerenchyma formation of rice roots in SRI method was $45 \%$, while the formation of aerenchyma in rice roots conventional method was 71\% (Table 4 and Figure 4).

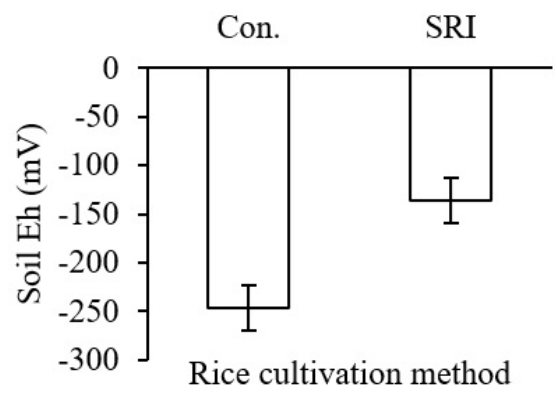

Figure 2. Effect of cultivation methods on soil Eh. Con.: conventional; SRI: System of Rice Intensification. Bar lines indicate standard error of independent t-test at $a=0.05$

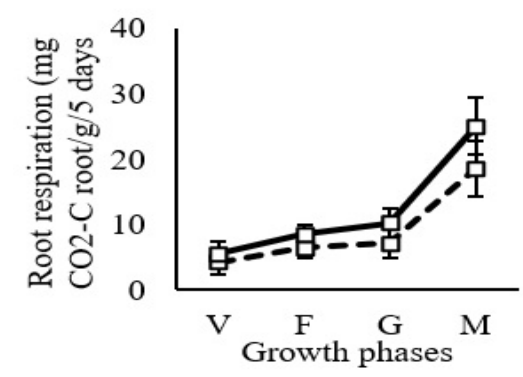

Figure 3. Effect of cultivation methods on root respiration in the four phases of growth (V: vegetative; $\mathrm{F}$ : flowering; G: grain filling; M: mature grain). --口-- : Conventional; $\rightarrow \square-$ : SRI. Bar lines indicate standard error of independent t-test at $a=0.05$

Table 4. Effect of cultivation methods on root aerenchyma at 70 day after sowing

\begin{tabular}{lc}
\hline Rice cultivation method & Root aerenchyma area (\%) \\
\hline Conventional & $70.9 \pm 7.83 \mathrm{~b}$ \\
SRI & $45.1 \pm 5.06 \mathrm{a}$ \\
\hline
\end{tabular}

The same letter in the same column was not significantly different with Independent t-test at $a=0.05$

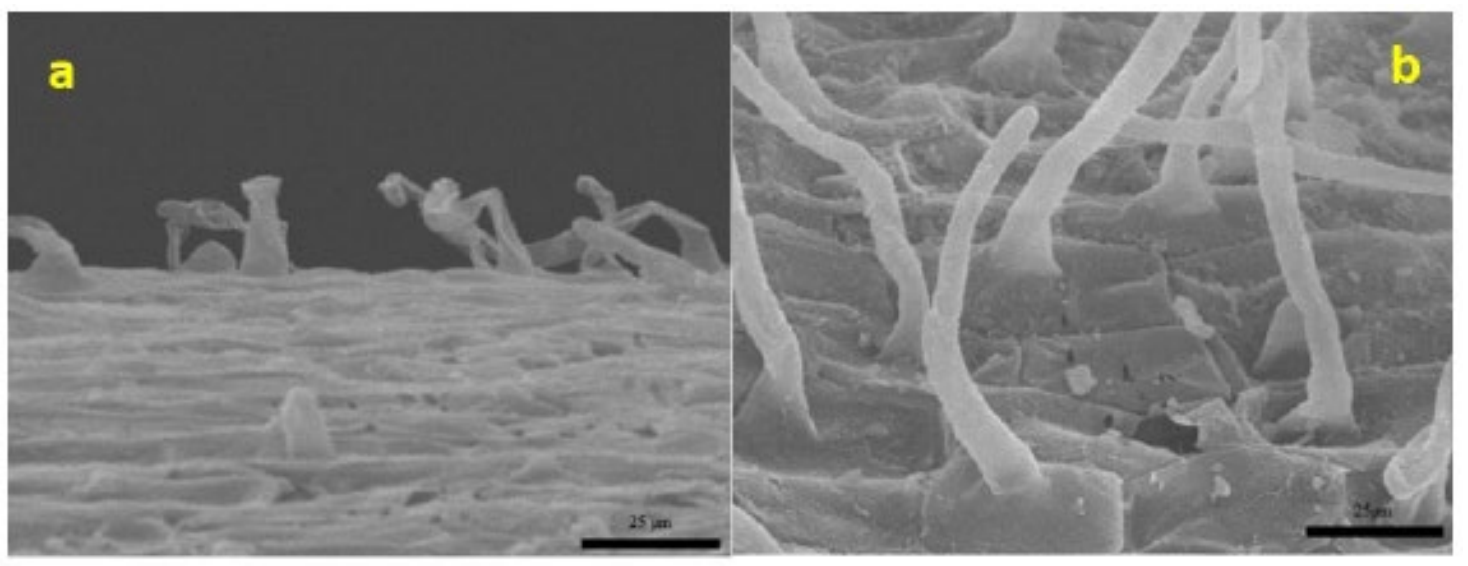

Figure 1. Observations of rice root hairs at 70 days after sowing, using SEM JEOL JSM-5310LV type, magnification of $1000 x$ : a) the root hairs at $\geq 1 \mathrm{~cm}$ from the root tip in the conventional method; b) the root hairs at $\geq 1 \mathrm{~cm}$ from the root tip in the SRI method 

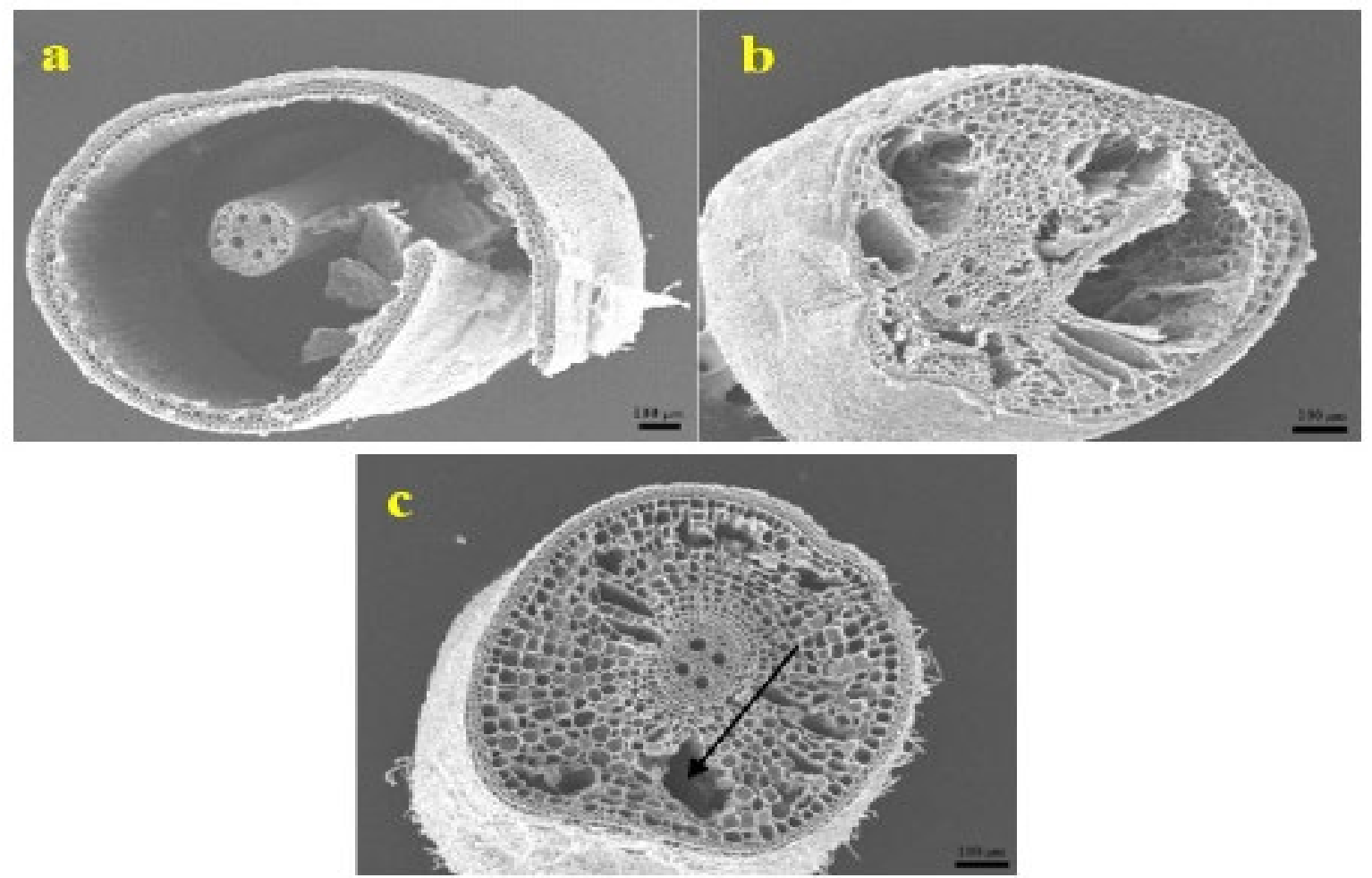

Figure 4. Observations of aerenchyma in rice root at 70 days after sowing, using a SEM JEOL JSM-5310LV type, magnification of $100 \mathrm{x}$. $\rightarrow:$ aerenchyma. a) Root aerenchyma at $2 \mathrm{~cm}$ from the root tip in the conventional method; b) Root aerenchyma at $1 \mathrm{~cm}$ from the root tip in the conventional method; c) Root aerenchyma at $1 \mathrm{~cm}$ from the root tip in the SRI method

\section{Discussion}

The soil moisture regime and the wide spacing in the System of Rice Intensification (SRI) methodology make the roots grow more vigorously and to develop optimally in well-oxidized soil. The length of rice roots in the SRI method is greater than with the conventional method, because of the soil moisture and well-aerated soil in the SRI method which has a major impact on root growth, root viability, and ultimately also affects plant growth (Huang 1999). Root growth SRI method reaches 2.75 times more length compared to conventional method; this effect can be attributed in part to wider spacing between plants in SRI method (Hameed et al. 2011).

The increase in root dry weight with the SRI method was partly attributable to root length being longer than that of the conventional method (Table 2). The application of SRI method could increase root depth, root dry weight, root volume, root length, and root density (Thakur et al. 2011). Transplanting at seedling age of 10 days, one seedling per hill, and wider spacing in the SRI method allows higher nutrient availability for plants' root systems due to reduced competition among plants than with the conventional method.

This leads to an increase in the character of the roots, namely root length, root volume, and root dry weight, and making for higher photosynthetic activity because the roots can provide more optimum nutrition for the whole plant that the plants can grow in accordance with their potential (Rani 2013). Meanwhile, with conventional method, the root length and root dry weight were lower than of SRI method. Based on an evaluation of the root growth of rice comparing the effects of continuous flooding vs. intermittent provision of water, it has been found that by the flowering phase about $78 \%$ from the roots will degenerate under the condition of flooded rice field compared to almost no degeneration in well-drained soils (Kar et al. 1974).

One very obvious way in which the root development with SRI method is better than with conventional method is seen in the higher number of root hairs in the SRI method plants compared with conventional method. Root hairs are particularly important for higher absorption of water and nutrients from the soil (Table 3). The growth of root hairs was found to increase in the top soil layer in SRI method. Some plants will form a greater system of root hairs in moist, but well aerated soil conditions (Salisbury and Ross 1992). Rice root hairs growth and development were inhibited by anoxic condition as in the conventional method. Anoxic submergence is predicted to have several metabolic and physiological consequences, including low ATP availability due to limited respiration, depletion of carbohydrate stores, excessive reactive oxygen species formation and a decrease in root hydraulic conductivity. The growth and development of rice 
root hairs in water logged-soil were controlled by OsHF1 gene (Huang et al. 2013).

Root hairs of rice grown under SRI method also look better in appearance (Figure 1). The healthy root hairs tend to grow straight and have a large surface area, so that the plants can absorb most of the water and nutrients through their root hairs (Bates and Lynch 1996). Meanwhile, the root hairs of rice in conventional method was apparently damaged (aerenchyma has formed), so that the appearance was not as good as the root hairs of rice in the SRI method which looks not rigid (wilt) (Figure 1). The roots are the part of plants that are in direct contact with the soil for absorption of nutrients in the soil. The root hairs with their large surface area relative to weight and diameter can substantially increase the contact of roots with the soil, so the root hairs can help plants absorb the limited nutrients in the soil such as nitrogen and phosphorus (Gahoonia et al. 1997).

However, the better development of roots with SRI method did not make for a higher rate of root respiration than with conventional method. Root respiration in rice plants under SRI management was not significantly different from that of plants with conventional management (Figure 3), although the root respiration in the SRI method tended to be higher. It is presumably because the rice plants have the ability to make root aerenchyma (Table 4 and Figure 4). Aerenchyma formation in roots rice under conventional method presumably cause by hypoxia when soil flooded. Hypoxia or low oxygen stimulates plants to produce ethylene. Ethylene slows down to primary and adventitious roots. The extent of aerenchyma (interconnected gas-filled space) formed in the cortex of the roots of rice plants can be promoted by submergence and ethylene (Yukiyoshi and Karahara 2014). Aerenchyma serves to accommodate the $\mathrm{O}_{2}$, so the rice plants in the conventional method could still perform aerobic respiration in condition of flooded rice field. However, it was not impossible that the roots in the conventional method also perform anaerobic respiration because the value of soil Eh is lower than the SRI method (Figure 2). Low value of soil Eh indicates that the soil was reductive (Mer and Roger 2013).

During anaerobic respiration of root, potentially toxic metabolites such as ethanol, lactic acid, acetaldehyde, and cyanogen compounds can accumulate in plants. Eventually, cytosolic acidosis can occur within cells, due to the accumulation of lactic acid in the cytoplasm, which leads to cell death. Therefore, under flooding conditions, there were usually more dead roots found (Miro and Ismail 2013).

The higher formation of root aerenchyma in the conventional method greatly impacts plant growth due to aerenchyma tissue being formed, causing structural damage or at least deformation in plant roots. The formation of root aerenchyma takes $30-40 \%$ of root cortex which can potentially diminish the distribution of nutrients from the roots throughout the plant. If more and more aerenchyma tissue is formed, it will interfere with the absorption of nutrients and water by plant roots (Sumardi 2007). In addition, the rice plants require large amounts of energy for the formation and activity of aerenchyma cells to supply $\mathrm{O}_{2}$, resulting in reduced energy for plant growth, especially for tillering, thus the number of tillers is decreased compared to the no-flooding conditions (Bakrie et al. 2010).

In rice plants, the formation of aerenchyma not only occurs in the roots but can occur also in the stem (Yamauchi et al. 2013). Aerenchyma are usually formed in the cortex of roots and rhizomes. These are often termed lacunae (Armstron 1979), or simply, air pockets. Aerenchyma are formed at behind the apical meristem (Malik et al. 2003). The flooded rice plants after 3 days may result in an increase in the formation of aerenchyma in the whole stem segments, which shows that all the pre-aerenchymal cells are responsive to cell death and triggering signals for cell lysis. In addition, the trigger of the formation of aerenchyma is $\mathrm{H}_{2} \mathrm{O}_{2}$ (hydrogen peroxide) (Steffens et al. 2011).

Improvements in the rice roots system with SRI management method could improve the transportation of nutrients and minerals from the soil to the shoot, so it would support better shoot growth. Better shoot growth, especially of the leaves, would enhance the availability of photosynthate to be distributed to the roots, so that the roots grow up optimally. These demonstrate a relationship of mutual dependence which was called the root-shoot interaction (Samejima 2004).

The SRI method had a major effect on the rootshoot interaction, thus supporting a higher rice production. The SRI method of cultivation significantly increased rice production (ca. 24\%) compared to the conventional method in the same research (Hidayati et al. 2014). The changes in crop and water management can improve the expression of rice plants' genetic potential, thereby creating more productive and robust phenotypes from given rice genotypes (Uphoff et al. 2015).

From the data of hair roots performance we would like to state that rice plants cultivated under conventional management are a stressed plant. It has the impact in the difficulty of increasing rice yields in conventional farming (submergence system).

\section{Conclusion}

SRI method was able to improve the root length by $16 \%$ at 110 DAS, root dry weight by $65 \%$ at 70 DAS and $67 \%$ at 110 DAS compared to the conventional method. The SRI method was also able to increase the number of root hairs by $60 \%$ compared with 
the conventional method. Eh measurement in the soil with SRI management method was higher than with conventional method. However, there was no significant different in root respiration. The aerenchyma formation of rice roots in SRI method (45\%) was lower than conventional method (71\%).

\section{Acknowledgements}

The study was funded by Lembaga Pengelola Dana Pendidikan (LPDP) from Indonesian Government on behalf first author. We are grateful to staff of Plant Physiology Laboratory, Department of Biology, and Soil Biotechnology Laboratory, Department of Soil Science and Land Resources, Bogor Agricultural University (IPB), Indonesia. We would also like to thanks to Prof. Norman Uphoff from Cornel University, America for helping correction of the manuscript draft.

\section{References}

Armstrong W 1979. Aeration in higher plants. Adv Bot Res 7:225-331.

Anas I 1989. Biologi Tanah dalam Praktek. Bogor(ID): IPB Pr.

Bakrie MM et al. 2010. Aplikasi pupuk anorganik dan organik hayati pada budidaya padi SRI (System of Rice Intensification). J Tanah Lingk 12:25-32.

Bates TR, Lynch JP. 1996. Stimulation of root hair elongation in Arabidopsis thaliana by low phosphorus availability. Plant Cell \& Environ 19:529-538.

Barison J, Uphoff N. 2010. Rice yield and its relation to root growth and nutrient-use efficiency under SRI and conventional cultivation: an evaluation in Madagascar. Paddy Water Environ 9:65-78.

Bozzola JJ, Russel LD. 1999. Electron Microscopy Principles and Techniques for Biologist. Canada(US): Southern Illinois University Pr.

Fu S et al. 2008. A simplified system for measuring rhizosphere respiration of fine roots in situ. Forest Ecol \& Manage 255:3360-3364.

Gahoonia TS et al. 1997. Root hairs and phosphorus acquisition of wheat and barley cultivars. Plant \& Soil 191:181-188.

Hameed KA et al. 2011. Irrigation water reduction using system of rice intensification compared with conventional cultivation methods in Iraq. Paddy Water Environ 9:121-127.

Hidayati $\mathrm{N}$ et al. 2014. Physiological and morphological changes in rice plants under System of Rice Intensification (SRI) management and its effects on increasing yield. Presented at the $4^{\text {th }}$ International Rice Congress, Bangkok, Oct. 28-31.

Huang BR. 1999. Water relations and root Activities of Buchloe dactyloides and Zoysia japonica in response to localized soil drying. Plant and Soil 208:179-186.

Huang J et al. 2013. Formin homology 1 (OsHF1) regulated submergence-dependent root hair development in rice plants. Plant Signaling \& Behavior 8:1-2.

Kar S et al. 1974. Nature and growth pattern of rice root system under submerged and unsaturated condition. I1 Riso 23:173-179.

Kirk GJD, Solivas JL. 1997. On the extent to which root properties and transport through the soil limit nitrogen uptake by lowland rice. European J Soil Sci 4:613-621.
Kozlowski TT. 1997. Soil moisture and absorption of water by tree root. J Arboriculture 13:39-46.

Kramer PJ, Boyer JS. 1995. Water Relations of Plants and Soils. San Diego (USA): Academic Pr.

Laulanie HD. 1993. System of rice intensification. Tropicultura $11: 1-19$

Lin XQ et al. 2011. Effects of water management and organic fertilization with SRI crop practices on hybrid rice performance and rhizosphere dynamics. Paddy Water Environ 9:33-39.

Malik AI et al. 2003. Aerenchyma formation and radial $\mathrm{O}_{2}$ loss along adventitious roots of wheat with only the apical root portion exposed to $\mathrm{O}_{2}$ deficiency. Plant Cell \& Environ 26:1713-1722.

Mer JL, Roger P. 2013. Production, oxidation, emission and consumption of methane by soils: A review. Eur J Soil Biol 7:25-50.

Miro B, Ismail AM. 2013. Tolerance of anaerobic conditions caused by flooding during germination and early growth in rica (Oryza sativa L.). Frontiers in Plant Science 4:1-18.

Purnomobasuki H, Suzuki M. 2004. Aerenchyma formation and porosity in root of a mangrove plant, Sonneratia alba (Lythraceae). J. Plant Res 117:465-472.

Rani S, Sukumari P. 2013. Root Growth, nutrient uptake and yield of medicinal rice Njavara under different establishment techniques and nutrient sources. Americ J Plant Sci 4:1568-1573.

Salisbury FB, Ross CW. 1992. Plant Physiology. Belmont: Wadsworth Publishing Company.

Samejima H. 2004. Root-shoot interaction as a limiting factor of biomass productivity in new tropical rice lines. Soil Sci Plant Nutr 50:545-554.

Steffens B et al. 2011. Aerenchyma formation in the rice stem and its promotion by $\mathrm{H}_{2} \mathrm{O}_{2}$. New Phytol 190:369-78.

Sumardi. 2007. Respon padi sawah pada teknik budidaya secara aerobik dan pemberian bahan organik. Akta Agrosia 7:65-70.

Thakur AK et al. 2011. Effect on rice plant morphology and physiology of water and associated management practies of the system of rice intensification and their implications for crops performance. Paddy Water Environ 9:13-24.

Uphoff N, Randriamiharisoa R. 2002. Reducing water use in irrigated rice production with the Madagascar System of Rice Intensification (SRI). In: Water-Wise Rice Production: Proceedings of an International Workshop, April 8-11, 2002, eds. B.A.M. Bouman, 71-87. Intl. Rice Research Institute, Los Baños, Philippines.

Uphoff N. 2005. Agroecologycally-sound agricultural systems: can they provide for the world's growing populations? CIIFAD. USA: Cornell University.

Uphoff $\mathrm{N}$ et al. 2015. Improving the phenotypic expression of rice genotypes: Rethinking "intensification" for production systems and selection practices for rice breeding. The Crop J. (Available online 12 May 2015). 2015.http://dx.doi.org/10.1016/j.cj.2015.04.001.

Yamauchi T et al. 2013. Aerenchyma formation in crop species: A review. Field Crops Research 152:8-16.

Yukiyoshi K, Karahara I. 2014. Role of ethylene signalling in the formation of constitutive aerenchyma in primary roots of rice. AoB PLANTS. p. 1-9. 